\title{
Teaching NeuroImages: Vertebral artery compression by head tilt around the roll axis diagnosed by transcranial Doppler
}

Ji-Hyung Park, MD, Joomee Song, MD, Jaewon Shin, MD, Hyun-soon Jang, MD, and Woo-Keun Seo, MD, PhD Neurology ${ }^{\circledR}$ 2018;91:e1657-e1658. doi:10.1212/WNL.0000000000006389
Correspondence

Dr. Seo

mcastenosis@gmail.com

Figure 1 Magnetic resonance angiography of the head and neck

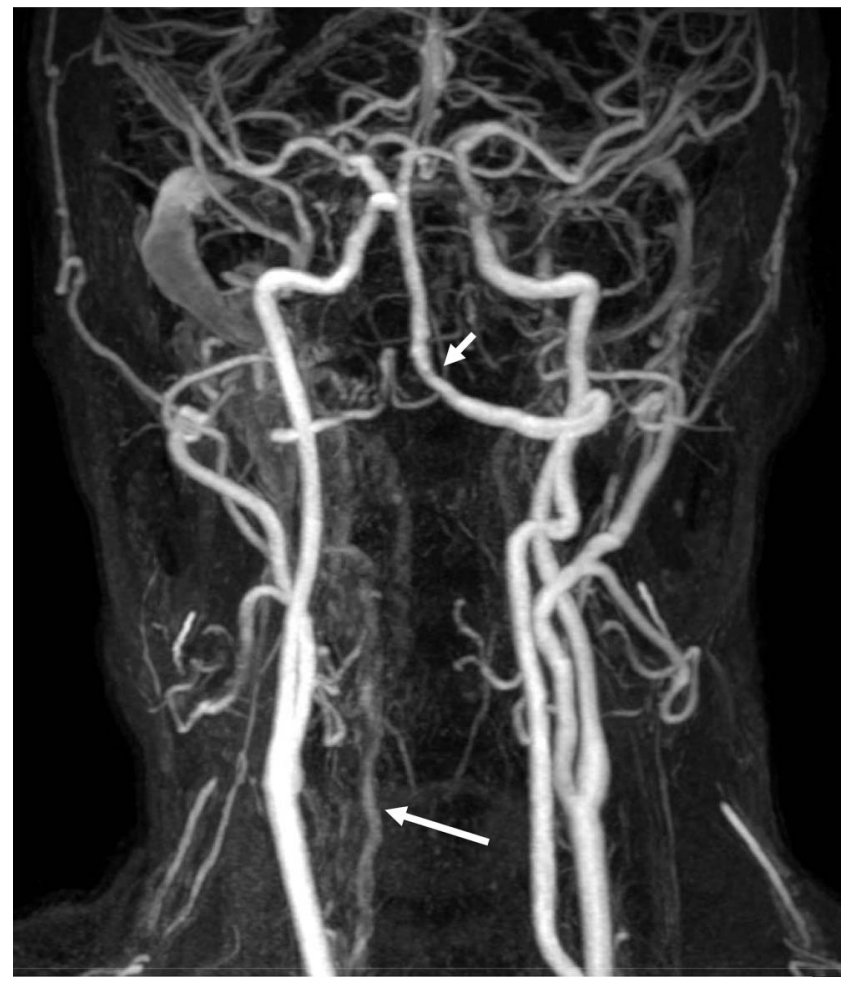

Contrast-enhanced magnetic resonance angiography shows hypoplasia of the right vertebral artery (long arrow) terminating in posterior inferior cerebellar artery and mild stenosis of the left vertebral artery (short arrow).

A 59-year-old man reported transient vertigo and diplopia during leftward head tilt around the roll axis. Neurologic examination was unremarkable with the head erect or tilted. Magnetic resonance angiography of the head and neck showed hypoplasia of the right vertebral artery (figure 1). Transcranial Doppler waveform was monitored during leftward head tilt. The left vertebral artery flow velocity decreased with tilt, and abruptly increased after returning to erect posture (figure 2). Vertebral artery can be stretched or kinked by head rotation or tilt, ${ }^{1,2}$ typically at the C1-2 level. ${ }^{1}$ Transcranial Doppler could be helpful in diagnosis of such cases.

\section{MORE ONLINE}

$\rightarrow$ Teaching slides

links.lww.com/WNL/

A717

\section{Author contributions}

J.-H. Park: study concept and design, drafting of the manuscript. J. Song: study concept and design, drafting of the manuscript. J. Shin: study concept and design, critical revision of manuscript for intellectual content. H.-S. Jang: study concept and design, critical revision of manuscript for 
Figure 2 Transcranial Doppler monitoring of the left vertebral artery
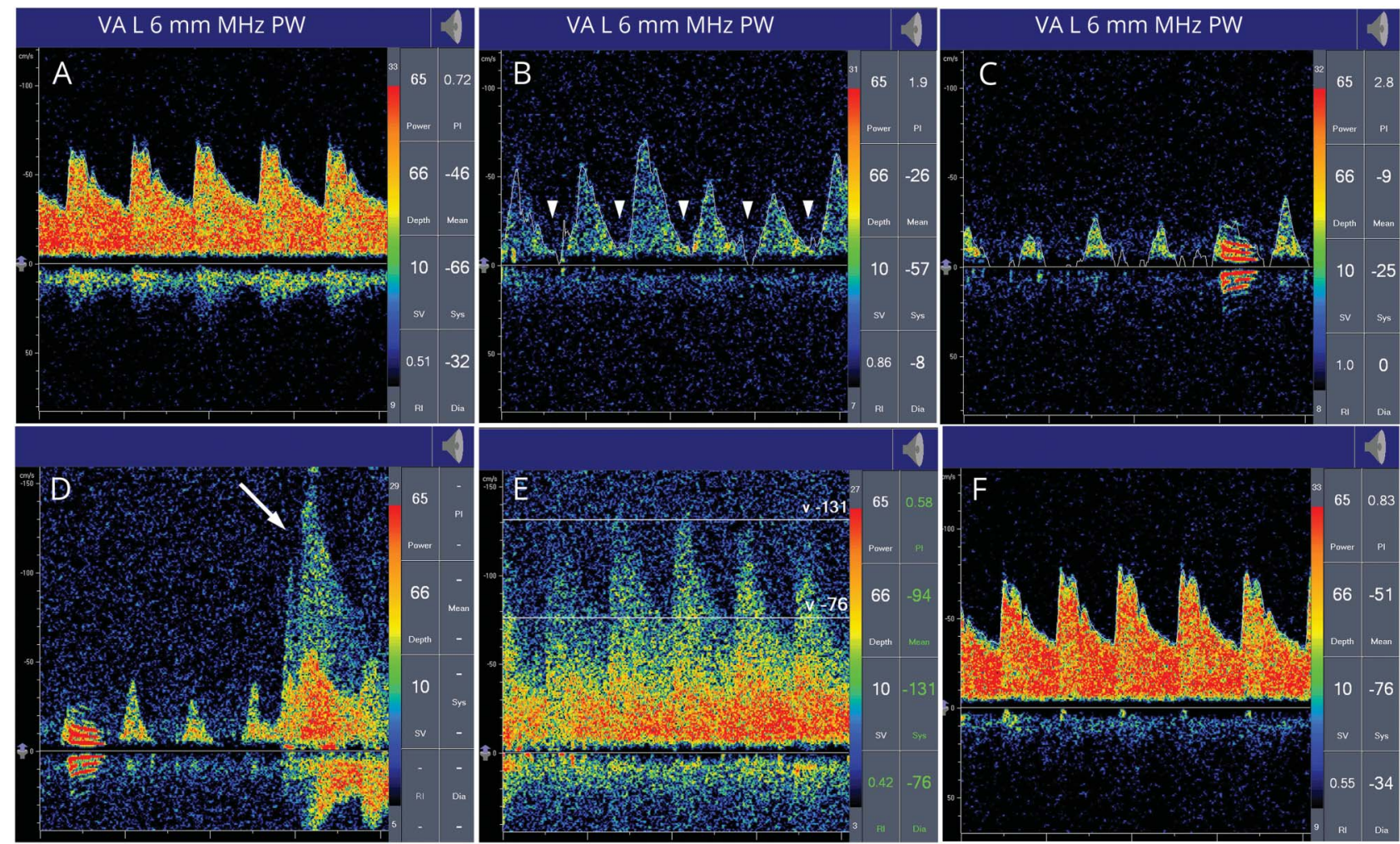

(A) Normal waveform with erect neck posture. (B, C) After left head tilt, diastolic velocity decreased first (arrowheads) and systolic velocity decreased later. (D, E) When erect posture was assumed, flow velocity dramatically increased immediately (arrow) and (F) normalized after about 2 minutes.

intellectual content. W.-K. Seo: study concept and design, critical revision of manuscript for intellectual content.

\section{Acknowledgment}

The authors thank Hyun Kyung Lee for acquisition of the transcranial Doppler data and Eun Son Lee for data management.

\section{Study funding}

No targeted funding reported.

\section{Disclosure}

The authors report no disclosures relevant to the manuscript. Go to Neurology.org/ $\mathrm{N}$ for full disclosures.

\section{References}

1. Choi $\mathrm{KD}$, Choi JH, Kim JS, et al. Rotational vertebral artery occlusion: mechanisms and long-term outcome. Stroke 2013;44:1817-1824.

2. Choi JY, Seo WK, Oh K, Seo SI, Ryou N, Chae SW. Vertebral artery compression during roll tilt: is the edge of the foramen magnum a culprit? J Clin Neurol 2015;11: 292-294. 


\section{Neurology}

\section{Teaching NeuroImages: Vertebral artery compression by head tilt around the roll axis diagnosed by transcranial Doppler}

Ji-Hyung Park, Joomee Song, Jaewon Shin, et al. Neurology 2018;91; 1657-e1658

DOI 10.1212/WNL.0000000000006389

This information is current as of October 22, 2018

\section{Updated Information \&} Services

References

Subspecialty Collections

Permissions \& Licensing

Reprints including high resolution figures, can be found at: http://n.neurology.org/content/91/17/e1657.full

This article cites 2 articles, 1 of which you can access for free at: http://n.neurology.org/content/91/17/e1657.full\#ref-list-1

This article, along with others on similar topics, appears in the following collection(s):

Other cerebrovascular disease/ Stroke

http://n.neurology.org/cgi/collection/other_cerebrovascular_disease_s troke

Ultrasound

http://n.neurology.org/cgi/collection/ultrasound

Vertigo

http://n.neurology.org/cgi/collection/vertigo

Information about reproducing this article in parts (figures,tables) or in its entirety can be found online at:

http://www.neurology.org/about/about_the_journal\#permissions

Information about ordering reprints can be found online:

http://n.neurology.org/subscribers/advertise

Neurology ${ }^{\circledR}$ is the official journal of the American Academy of Neurology. Published continuously since 1951, it is now a weekly with 48 issues per year. Copyright @ 2018 American Academy of Neurology. All rights reserved. Print ISSN: 0028-3878. Online ISSN: 1526-632X.

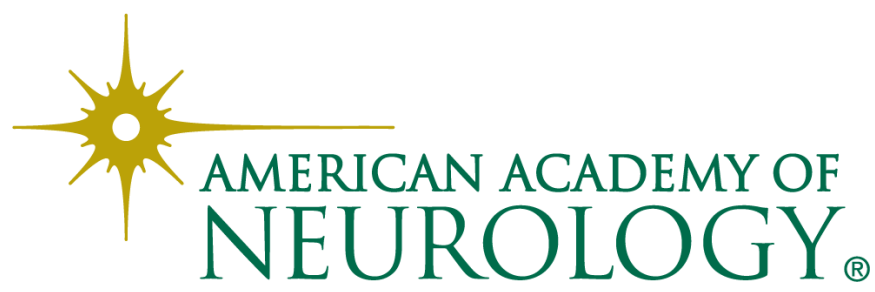

